\title{
Competencies and professional development needs of kindergarten teachers
}

\author{
Phoebe L. Gallego ${ }^{1}$, Manuel E. Caingcoy ${ }^{2}$ \\ ${ }^{1}$ Department of Education, Division of Sultan Kudarat, Kenram, Isulan, Sultan Kudarat, Philippines \\ ${ }^{2}$ Bukidnon State University, Malaybalay City, Bukidnon, Philippines \\ Email:phoebelgallego@mail.com ${ }^{1}$, caingcoymanuel@gmail.com ${ }^{2}$ \\ ORCID ID: 0000-0002-3862-1561
}

\begin{abstract}
The study identified the level of competencies and the extent of professional development needs of kindergarten teachers in the Sultan Kudarat Division, during the school year 2019 - 2020. The study employed a descriptive method. The study involved 54 kindergarten teachers in the division in accomplishing the 12 -item self-assessment instrument. Data were analyzed using descriptive statistics. The results revealed that kindergarten teachers have a high level of competencies in content knowledge and pedagogy, learning environment and diversity of learners, curriculum and planning, and assessment and reporting. These indicate that they possess almost all of the competencies of efficient teachers. Results further revealed a very high extent of professional needs in content knowledge and pedagogy and the learning environment and diversity of learners, while they had a high extent of professional needs in the remaining domains. Since they reported very high priorities in content knowledge and pedagogy and the learning environment and diversity of learners, these areas would be the main considerations in the crafting of a professional development plan.
\end{abstract}

Keywords: Competencies, professional development needs, kindergarten teachers

\section{INTRODUCTION}

Efficient teaching requires the necessary competencies. These are important in ensuring the achievement of educational goals. Competencies are the standards in determining whether an employee has skills in performing their tasks relevant to the job. Competencies are necessary for teachers. Improving their competencies means improving the quality of teaching and learning. Consequently, teachers need professional development to enhance their competencies in the teaching profession. The competencies of teachers are important in determining the success of the teaching and learning process. Zamri et al. (2019) described competencies as a set of standards necessary for teachers to master various educational proficiencies to achieve current educational needs. Teachers' competencies relate to their values, behavior, communication, aims, and practices, as well as support professional development and curricular studies. This shows that teachers' competencies for the improvement of the teaching-learning process in school are of great importance (Selvi, 2016). Hence, enhancing the competencies of teachers requires professional development.

One consistent finding in educational research is that improvements in education rarely take place in the absence of professional development (Guskey, 2013). Professional development is the key to meeting today's educational challenges. Accordingly, the participation of teachers in professional development activities remarkably manifested positive effects on teachers' beliefs and practices, students' performance in learning, and on educational improvement. Professional development is the center of lifelong learning and has a huge impact on teaching practice and achieving students' needs (Tanang \& Abu, 2014). Kindergarten teachers are among the groups that influence the education of children. They are the ones who deal with kindergarten learners in their formative years. They spend long periods with these children, and thus, they may have a positive or negative influence on the character of children (Board on Children, Youth, and Families, 2015). The quality of this formative phase depends largely on the quality of teachers. Therefore, by engaging in various professional development activities, this greatly enhances the competence of kindergarten teachers.

In the municipality of President Quirino and Lambayong, Sultan Kudarat Division, seven training were conducted for kindergarten teachers in the past three years. However, in some of these training, not all kindergarten teachers have attended. Only selected and qualified kindergarten teachers were allowed to attend. Only three teachers from the President Quirino Municipality and three from the Municipality of Lambayong were advised to participate. There was very limited training provided to kindergarten teachers in these two municipalities, and most of them are not graduates of early childhood education. Also, local-based providers of CPD in these two municipalities are few, since training in these two municipalities is at the division level. Further, considering the number of kindergarten teachers in the division, not all kindergarten teachers are allowed to participate. Accommodating all kindergarten teachers in the division could cause a shortage of budget, in the 
way that the division could spend a lot of its financial resources, as the division needs to provide housing to the participants of the training. They could also spend much time as they need to travel from their respected stations to the venue. The researcher focused on kindergarten because she is one of the kindergarten teachers in one of the locales of the study. As a kindergarten teacher for almost seven years, the researcher has the first-hand experience of having limited training. The average individual performance commitment and review (IPCR) rating of kindergarten teachers in President Quirino and Lambayong is 3.881, with an adjectival rating of very satisfactory. However, this rating cannot be a gauge that teachers are competent enough in teaching and handling their students. Further, despite the studies conducted on professional development for kindergarten teachers, there are no studies conducted aligning professional development of these teachers to their needs and perceived level of competencies.

Aligning the training provided to kindergarten teachers with their professional and competency needs is vital to ensuring effectiveness in teaching children that can be accounted for by their professional growth. Allan (2008) suggested that interactive professional development training programs are needed to provide opportunities for on-going monitoring and feedback of observed instructional practice to improve instructional practice in teaching. It was also recommended that division kindergarten coordinator and elementary principals are to provide professional development opportunities and training designed to direct kindergarten teachers to integrate the teaching of personal and social skills while teaching content area skills in the academic arena (Ho, n.d.). The categorization of the teaching staff according to individuals' professional desires can serve as a vital tool to help administrators analyze teachers' courses of professional development and could be used to design professional development programs that will match the needs of teachers (Avidov-Ungar, 2018).

The study determined the level of competencies and professional development needs of kindergarten teachers of the municipality of President Quirino and Lambayong, Sultan Kudarat Division in the school year 2019-2020, on the following domains: content knowledge and pedagogy, learning environment and diversity of learners, curriculum and planning, and assessment and reporting. This study provided research-based information to the selected school heads and other concerned officials in the division. It generated knowledge that can be made the basis for designing training at the district level. This was to ensure that the training to be conducted to kindergarten teachers are responsive to their needs and competencies.

\section{METHODOLOGY}

This study utilized descriptive research in identifying the competencies and professional development needs of 54 kindergarten teachers. The study was conducted at President Quirino and Lamabyong Elementary Schools, Sultan Kudarat Division. It involved kindergarten teachers and the substitute teachers in which 27 came from President Quirino, while the other 27 came from the Lambayong. These teachers were graduates of Bachelor in Elementary Education, and they have earned units in early childhood education. The study made use of the self-assessment tool intended for teachers I, II, and III. This was developed by the Department of Education - Bureau of Human Resource and Organizational Development (2017). It has 12 indicators adapted from the Philippine Professional Standards for Teachers (PPST) developed by Philippine National Research Center for Teacher Quality (2017). Specifically, these indicators represented the teacher standard domains such as the content knowledge and pedagogy, another three items on the learning environment and diversity of learners, three items on curriculum and planning, and three items on assessment and reporting. This 12-item tool underwent a process of validation. In each item, the teachers evaluated themselves twice. The first column identified the level of their competencies while the second column determined their professional needs. The mean and standard deviation were used in determining the competencies and professional needs of kindergarten teachers.

\section{RESULTS AND DISCUSSION}

\subsection{Competency in Content Knowledge and Pedagogy}

Kindergarten teachers are expected to be competent in content knowledge and pedagogy. The content knowledge refers to different areas of the early childhood education curriculum. Also, this is the ability of the kindergarten teachers to apply developmentally appropriate and meaningful pedagogy grounded on content knowledge and current research. This includes their proficiency in the mother tongue, the Filipino, and English languages in teaching and learning within the curriculum. It also takes into account the skills in communication, teaching strategies, and technologies that promote high-quality learning outcomes. Table 1 presents the competency level of kindergarten teachers in content knowledge and pedagogy. The overall results show a high level of competency that indicated they possessed most of the competencies of efficient teachers in content knowledge and pedagogy. Indicator 1 on applying knowledge of content within and across curriculum teaching areas has the highest mean and is described as a high level of competency. Still on a high level of competency is indicator 2 on using a range of teaching strategies that enhance learner achievement in literacy and numeracy skills. However, applying a range of teaching strategies that develop critical and creative thinking, as well as 
higher-ordered thinking skills, got the lowest mean which indicates a moderate level of competency. Moreover, the frequency of the responses of the participants in the 3 indicators is almost the same and not widely spread. This means that most of them have the same level of competency in the 3 indicators.

Table 1. Competency of Kindergarten Teachers in Content Knowledge and Pedagogy

\begin{tabular}{|c|c|c|c|}
\hline Indicators & Mean & SD & $\begin{array}{l}\text { Qualitative } \\
\text { Description }\end{array}$ \\
\hline $\begin{array}{l}\text { 1. Applied knowledge of content within and across curriculum } \\
\text { teaching areas. }\end{array}$ & 3.66 & 0.51 & High \\
\hline $\begin{array}{l}\text { 2. Used a range of teaching strategies that enhance learner } \\
\text { achievement in literacy and numeracy skills. }\end{array}$ & 3.40 & 0.49 & High \\
\hline $\begin{array}{l}\text { 3. Applied a range of teaching strategies to develop critical and } \\
\text { creative thinking, as well as other higher-order thinking skills. }\end{array}$ & 3.35 & 0.48 & Moderate \\
\hline Overall & 3.47 & 0.39 & High \\
\hline
\end{tabular}

The results imply that the participants are knowledgeable about what to teach and how to teach it, and they also have acquired a reasonable extent of knowledge on the content standards of the curriculum. This means that they can demonstrate a range of suitable and appropriate pedagogies depending on the content to be delivered to learners. This also means that the participants model exemplary practice in improving the applications of content knowledge within and cross-curriculum teaching areas. Moreover, they are exemplary in using classroom strategies that support learner understanding, participation, engagement, and achievement in different learning contexts. These may be attributed to years of experience, continuing professional development, LAC sessions, and mentoring in the workplace.

Further, the results of the study show that continuing professional development could be a contributor to enhancing the competencies of teachers, especially in the aspect of content knowledge and pedagogy competency. This affirmation supports the claims of Zhang et al. (2015), who said that the competence of teachers in content knowledge and pedagogy was ascribed from teachers' development and professional training. They said that improving teachers' content knowledge through professional development is necessary. The same affirmation was drawn in the study conducted by Lucenario et al. (2016). The LAC is an example of school-based professional development that could also contribute to the improvement of teachers' teaching practice, as well as teachers' competence in content knowledge and pedagogy. This observation supports the claim of DepEd (2016) in DepEd Order 35 series of 2016, stating that LAC is one of the professional development programs that develop the potentials teachers in the department. Mentoring in the workplace plays significantly in developing teachers' competence in content knowledge and pedagogy as manifested in collaborating, interacting, and sharing experiences. This realization is parallel to the findings of Lee (2011), which stated that coaching or mentoring and collaborating with other teachers can greatly enhance teachers' pedagogical content knowledge. This claim is also supported by the notion of Lucenario et al. (2016) and Evens et al. (2015) which stated that sharing ideas and expertise with colleagues could develop teachers' competence.

\subsection{Competency in Learning Environment and Diversity of Learners}

Kindergarten teachers are expected to possess the competency in the learning environment and diversity of learners. Possessing this competency, kindergarten teachers can influence good learning. This competency focuses on the role of teachers in providing a safe, secure, fair, and supportive learning environment that promotes learner responsibility and achievement. It also emphasizes the main role of teachers in making learning environments that are open to learner diversity. The main concern of this competency is to create an environment which is learning-focused, in which teachers can manage learner behavior efficiently in physical and virtual space, and it gives importance on the knowledge and understanding of teachers, as well as the respect in the different characteristics and experiences of the learners as the basis in the planning and designing of learning opportunities. It also centers on teachers' needs in utilizing a range of resources. It focuses on providing intellectually challenging and stimulating activities that encourage constructive classroom interactions for higher standards of learning. It also encourages differentiated teaching practices for learners to be successful citizens.

Table 2. Competency of Kindergarten Teachers in Learning Environment and Diversity of Learners

\begin{tabular}{llll}
\hline Indicators & Mean & SD & $\begin{array}{l}\text { Qualitative } \\
\text { Description }\end{array}$ \\
\hline $\begin{array}{l}\text { 1. Managed classroom structure to engage learners, individually or } \\
\text { in groups, in meaningful exploration, discovery, and hands-on } \\
\text { activities within a range of physical learning environments. }\end{array}$ & & 0.53 & High \\
& &
\end{tabular}




\begin{tabular}{|c|c|c|c|}
\hline $\begin{array}{l}\text { 2. Used differentiated, developmentally appropriate learning } \\
\text { experiences to address learners' gender, needs, strengths, } \\
\text { interests, and experiences. }\end{array}$ & 3.40 & 0.49 & High \\
\hline $\begin{array}{l}\text { 3. Managed leaner behavior constructively by applying positive and } \\
\text { non-violent discipline to ensure learning-focused environments. }\end{array}$ & 3.38 & 0.52 & Moderate \\
\hline Overall & 3.40 & 0.43 & High \\
\hline
\end{tabular}

Table 2 shows the competency level of kindergarten teachers in the learning environment and the diversity of learners. Generally, the level of the competency of kindergarten teachers in the learning environment and diversity of learners is high. This signifies that the teachers possessed most of the competencies of efficient teachers. In the three indicators: managing classroom structure to engage learners in individual or group handson activities with a meaningful exploration and discovery within a range of physical learning environments has the highest mean. This indicates a high level of competency. The level of competency of the participants in the second indicator on using differentiated, developmentally appropriate learning experiences in addressing learners' gender, needs, strengths, interests, and experiences is still ranged in a high level of competency. However, managing learners' behavior constructively through the application of positive and non-violent discipline in ensuring a learning-focused environment is at a moderate level. This would mean they possessed some of the competencies of efficient teachers. Besides, the frequency of responses of participants in the three indicators is almost the same and not widely dispersed. This infers that most participants have the same level of competencybased on these indicators. The competency results imply that these participants are well acquainted with how to manage their classroom and their learners. They are well-oriented that classroom should be child-friendly and must be organized properly to encourage learners to learn. They are also abreast of the different teaching strategies that can cater to individual differences, and they can address the different learning styles of their learners to ensure meaningful teaching and learning process. These may be due to the training and seminars attended by them and the benchmarking from the classrooms of other schools.

The study holds the implication that training and seminars attended by kindergarten teachers could enhance their teaching strategies and skills and could cater to the individual needs of their learners. This assertion supports the ideas of Tanang and Abu (2014), who said that effective training and seminars improve the quality of teachers' teaching practice. Also, through training and seminars, teachers' skills in addressing their students' needs by integrating technology in the classroom can encourage classroom interaction. This observation supports the statement of Amirul et al. (2013), which stated that integrating technology is important in meeting students' current needs as teachers' way of teaching and students' way of learning. Learning is constantly changing; integrating technology in the learning environment means that the environment was planned, designed, and wellconstructed. Likewise, this assertion is parallel to the findings of Özerem and Akkoyunlu (2015), who found that teachers who engage in training are geared with guidelines needed in preparing lesson contents that are suitable to students' learning styles. The learning environment is designed according to students' learning styles.

Additionally, learning environments should be designed according to students' learning styles. That is why benchmarking is essential in improving kindergarten teachers' abilities in designing classrooms suited to kindergarten learners. This claim supports the notion of Margarita and Ancheita (2005) which stated that it is important for the teachers to actively participate in the classroom design process, they should also visit other classrooms and interview co-teachers, staff as well as parents to obtain more knowledge for the development of classroom structures and facilities. Likewise, this assertion supports the claim of Jelas (2010), which stated that in a meaningful teaching and learning environment, teachers should consult or collaborate. It further supports the claim that kindergarten coordinators should frequently visit kindergarten classrooms to ensure students' participation, involvement, and understanding and, more importantly, to offer support to teachers who lack competencies required to improve learning situations and classroom environment (Malik et a., 2018).

\subsection{Competency in Curriculum and Planning}

The competency in curriculum and planning is necessary for kindergarten teachers. Having this competency, they can become efficient teachers. This competency addresses the national and local requirements of the knowledge and interaction of kindergarten teachers. It focuses on teachers' ability to translate curriculum content into learning activities based on the principles of effective teaching and learning suited to the learners. Kindergarten teachers are expected to apply their professional knowledge in planning and designing wellstructured and sequenced lessons, individually or in collaboration with other teachers. Lessons are sequenced, and learning programs that are related are contextually relevant, responsive to learners' needs, and incorporated in a range of teaching and learning resources. In this competency, kindergarten teachers are expected to communicate learning goals to support the participation, understanding, and achievement of the learners.

Table 3 illustrates the level of competency of kindergarten teachers in curriculum and planning. Looking at the overall mean, the level of competency of the participants in curriculum and planning is high. It reveals that these teachers possessed most of the competencies of efficient teachers. Looking at the results of the three indicators, participating in collegial discussions that use teacher and learner feedback in enriching teaching 
practice has the highest mean, which entails a high level of competency. This indicated that they possessed most of the competencies of efficient teachers. On the other hand, their level of competency in planning, managing, and implementing developmentally sequenced teaching and learning processes to meet curriculum requirements has the lowest mean with a moderate competency level. The level of competency in selecting, developing, organizing, and using appropriate teaching and learning resources, including ICT, in addressing learning goals has a moderate level. These results point out that in these two competency indicators, they possessed some of the competencies of efficient teachers.

\begin{tabular}{lccc}
\multicolumn{2}{c}{ Table 3. Competency of Kindergarten Teachers in Curriculum and Planning } \\
\hline Indicators & Mean & SD & $\begin{array}{l}\text { Qualitative } \\
\text { Description }\end{array}$ \\
\hline $\begin{array}{l}\text { 1. Participated in collegial discussions that use teacher and learner } \\
\text { feedback to enrich teaching practice. }\end{array}$ & 3.64 & 0.78 & High \\
$\begin{array}{l}\text { 2. Selected, developed, organized, and used appropriate teaching } \\
\text { and learning resources, including ICT, to address learning goals. }\end{array}$ & 3.35 & 0.70 & Moderate \\
$\begin{array}{l}\text { 3. Planned, managed, and implemented developmentally sequenced } \\
\text { teaching and learning processes to meet curriculum requirements } \\
\text { and varied teaching contexts. }\end{array}$ & & 0.46 & Moderate \\
\hline Overall & 3.43 & 0.43 & High \\
\hline
\end{tabular}

Furthermore, looking at the scores of the competency indicators, the answers of kindergarten teachers in planning, managing and implementing developmentally sequenced teaching and learning processes to meet curriculum requirements are not widely dispersed compared to their scores in selecting, developing, organizing and using appropriate teaching and learning resources, which includes ICT, in addressing learning goals, and in participating in collegial discussions using teacher and learner feedback in enriching teaching practice. This draws an implication that the level of competency of kindergarten teachers in planning, managing and implementing developmentally sequenced teaching and learning processes are approximately similar. Most kindergarten teachers have a moderate level of competency in this competency indicator. The results imply that these participants are proficient in translating curriculum content into learning activities suitable for kindergarten learners. They have attained the knowledge and skills in planning, structuring, and sequencing lessons. These may be due to their involvement in curriculum development and sequencing, planning, teaching, and learning processes. Also, their engagement in conferences and years of experience may have enhanced their teaching practice. The result of the study points to the fact that kindergarten teachers are expected to participate and apply their professional knowledge in planning and designing curriculum, and well-structured and properly sequenced lessons appropriate to their learners. This supports the claim of Chaudhary (2015), which said that it is a must to involve teachers in curriculum planning and development for them to implement it well and modify according to the needs of learners.

Through active engagement of the participants in conferences, they are proficient in translating curriculum content into learning activities for kindergarten learners. This assertion supports the ideas of Patankar and Jadhav (2013), who said that teachers as curriculum developers, should attend seminars, panel discussions, orientation programs, and workshops. They should take relevant programs for professional development. This assertion further conforms to the findings of Ghavifekr and Rosdy (2015) which found that professional development training programs for teachers to enhance quality teaching and learning. Further, great teaching experience could harness kindergarten teachers' effectiveness in translating curriculum content into teaching activities suitable to kindergarten learners. This affirms the findings of Nghihalwa (2018), which stated that experienced teachers have the necessary skills and knowledge that should be integrated into the curriculum.

\subsection{Competency in Assessment and Reporting}

The competency in assessment and reporting is essential for kindergarten teachers. With this competency, kindergarten teachers would become productive teachers. This competency is with the use of assessment data in different forms in informing and enhancing the teaching and learning process and programs. Teachers are expected to provide learners with necessary feedback about learning outcomes. This feedback notifies the reporting circle and allows teachers to select, organize, and use sound assessment processes. Table 4 presents the level of competency of kindergarten teachers in assessment and reporting.

Table 4. Competency of Kindergarten Teachers in Assessment and Reporting

\begin{tabular}{llll}
\hline Indicators & Mean & SD & $\begin{array}{l}\text { Qualitative } \\
\text { Description }\end{array}$ \\
\hline $\begin{array}{l}\text { 1. Communicate promptly and learners' needs, progress, and } \\
\text { achievement to key stakeholders, including parents/guardians. }\end{array}$ & & 0.79 & High \\
$\begin{array}{l}\text { 2. Monitored and evaluated learner progress and achievement using } \\
\text { learner attainment }\end{array}$ & & 0.70 & High
\end{tabular}


3. Designed, selected, organized, and used diagnostic, formative, and summative assessment strategies consistent with curriculum requirements.

\begin{tabular}{llll}
\hline Overall & 3.76 & 0.39 & High \\
\hline
\end{tabular}

Their overall level of competency in this indicator is high, which indicates that these teachers possessed most of the competencies of efficient teachers. Comparing the means of the three competency indicators, communicating promptly and the needs, progress, and achievement of learners to the stakeholders and parents or guardians has the highest. It is followed by monitoring and evaluating learner progress and achievement using learner attainment data. These indicators have a high level of competency. Whereas, the competency level of kindergarten teachers in designing, selecting, organizing, and using diagnostic formative and summative assessment strategies consistent with curriculum requirements has the lowest. Even so, it is still within the high level of competency category, signifying that these teachers possessed most of the competencies of efficient teachers.

By looking at the frequency of the responses of the participants in communicating promptly and learners' needs, progress, and achievement to key stakeholders, including parents/guardians are widely spread compared to the other competency indicators. The level of the competency of kindergarten teachers in communicating promptly and the needs, progress, and achievement of learners to the stakeholders, and parents or guardians are not similar. Most of these teachers have a high level of competence in this competency indicator. The results imply that the participants are equipped with different assessment tools and strategies to assess their learners evenly. They are knowledgeable and experienced in giving feedback to their learners, stakeholders, and parents. These may be associated with what they have learned in college during their pre-service teaching experiences, the length of their teaching experience, training, and mentoring in the workplace. The study holds the implication that the length of their teaching experience, pre-service teaching experience, and education could heighten participants' competence in designing, selecting, and organizing assessment strategies are in accordance to the curriculum requirements, and monitoring and evaluating learners' progress and achievement. This assertion supports the claim of Mertler (2003), who said that teachers' assessment skills are best learned from the classroom experience. Also, this supports the ideas of Sawari (2014), who said that what teachers learned from training and pre-service education about assessment must be put into practice to get real experiences and assess what is the effective and ineffective assessment.

Training increases kindergarten teachers' competence, knowledge, and skills in assessing and monitoring students and in communicating students' progress, achievements, and needs to their parents and the stakeholders. This affirmation is parallel to the findings of Tagele and Bedilu (2018), who found that it is essential to improve teachers' assessment literacy through professional development training and programs. There should be a great emphasis on teachers' continuous professional development activities. Further, kindergarten learners are assessed by teachers by observing their performance in class through a checklist. Kindergarten teachers should be trained well on how to use the checklist to achieve fair and reliable results in assessing their students. This assertion supports the findings of Nicholas (2015), who claimed that teachers did not judge their students evenly because they have different beliefs in their students' abilities. Lastly, mentoring in the workplace could also be one of the contributors to the participants' competence in assessment and reporting. Experienced teachers could share what they have learned through the years of teaching and their practices in assessing their students and in giving feedback to parents as well as to the stakeholders. This affirmation supports the claim of Tanang and Abu (2014), who said that on-going mentoring and support to teachers should be considered to improve the quality of teaching.

\subsection{Professional Development Needs in Content Knowledge and Pedagogy}

The means and standard deviations of the professional development need indicators of kindergarten teachers in content knowledge and pedagogy were analyzed and compared to describe the extent of their professional development needs. The results are presented in Table 5. The questionnaire measured the extent of the professional development needs of kindergarten teachers in content knowledge and pedagogy based on the participant's self-assessment. Generally, the extent of the professional development needs of participants in content knowledge and pedagogy is very high indicating that the participants have a high priority for intensive and extensive continuing professional development. The result reveals that among the three professional development needs indicators to develop critical and creative thinking, as well as other higher-order thinking skills, earned the highest response with a very high extent of need. Still, with a very high extent is using a range of teaching strategies that enhance learner achievement in literacy and numeracy skills. Applying knowledge of content within and across curriculum teaching areas has the lowest response with a very high extent of professional development needs, suggesting that kindergarten teachers have a high priority for intensive and extensive continuing professional development. As observed, their scores in the three professional development need indicators, the answers of kindergarten teachers in applying a range of teaching strategies to develop critical and creative thinking, as well as other higher-order thinking skills are not widely dispersed compared to the other two professional development need indicators. The results draw an implication that the participants yearn to develop 
their competency in content knowledge and pedagogy. They want to advance their mastery of content knowledge and its interconnectedness within and across curriculum areas, and critically understand theories and principles of teaching and learning and how to apply those. Further, the result implies that the participants needed professional development in applying a range of teaching strategies to develop critical and creative thinking, as well as in other higher-order thinking skills than the other two professional development need indicators.

\begin{tabular}{lccc} 
Table 5. Professional Development Needs of Kindergarten Teachers in Content Knowledge and Pedagogy \\
\hline Indicators & Mean & SD & $\begin{array}{l}\text { Qualitative } \\
\text { Description }\end{array}$ \\
\hline $\begin{array}{l}\text { Applied a range of teaching strategies to develop critical and } \\
\text { creative thinking, as well as other higher-order thinking skills. }\end{array}$ & 4.72 & 0.45 & Very High \\
$\begin{array}{l}\text { Used a range of teaching strategies that enhance learner } \\
\text { achievement in literacy and numeracy skills. }\end{array}$ & 4.66 & 0.54 & Very High \\
$\begin{array}{l}\text { Applied knowledge of content within and across curriculum } \\
\text { teaching areas. }\end{array}$ & 4.55 & 0.53 & Very High \\
\hline Overall & 4.64 & 0.39 & Very High \\
\hline
\end{tabular}

But, still, they have a high priority for intensive and extensive continuing professional development in the other two professional development need indicators. Furthermore, the result of the frequency of their responses draws an implication that the majority of the participants have a high priority for intensive and extensive continuing professional development in applying a range of teaching strategies to develop critical and creative thinking, as well as other higher-order thinking skills. This may be due to the participants' competency level in this indicator is moderate. The result of the study holds an implication that the participants highly needed professional development to enhance their competence in applying different teaching strategies to develop critical and creative thinking and higher-order thinking skills of their students. This assertion is parallel to the findings of Ajani et al. (2018), who said that due to teachers' active participation in professional development programs, teachers' skills in the delivery of educational instruction enhanced. Their teaching practices are effectively developed. They become more efficient in using varied teaching approaches in their lessons that promote effective learning and greater academic performance of learners. Further, this research supports the findings of Zaidi et al. (2018), who found that continuous professional development plays a significant role in increasing teachers teaching practices and varied teaching strategies that encourage meaningful teaching and learning. Other than that, the result of the study is comparable with the findings by Opfer and Pedder (2011). They claimed that it is essential to enhance teachers' content knowledge and classroom practices through professional development.

Furthermore, their overall professional development needs indicators result implies that these participants desire to engage in professional development in content knowledge and pedagogy as they highly needed it. This may be because they believe that there is a need to develop in their expertise in content knowledge and pedagogy and enhance their delivery of instruction to promote the high quality of learning outcomes. This realization supports the findings of Elliot (2019), Rahman et al. (2011), who said that teachers must get involved in continuing professional development focusing on pedagogical knowledge and content knowledge for them to enhance their skills in selecting and using appropriate teaching strategies for effective teaching and learning. Teachers who attended professional development training performed significantly better. Likewise, this supports the claim of Sağır (2014), who said that increased knowledge, due to rapid changes and transformations, teachers feel the need for continuous professional development.

Also, trainers should be skilled, have mastery of the content, and pedagogy to meet and address the development needs of the teachers. As one of the kindergarten teachers, the researcher observed that in some training and seminars she had attended, some of the trainers and speakers were not that experts the topics discussed in the said training and seminars. They are just trained for how many days to train other kindergarten teachers in a limited period. This realization supports the ideas of Shendy et al. (2017), who said that professional development program trainers should be those subject matter experts, to completely impart knowledge for teachers to grasp a deeper understanding and have enriching learning experiences.

\subsection{Professional Development Needs on Learning Environment and Diversity of learners}

To describe the extent of the professional development needs of kindergarten teachers in the learning environment and diversity of learners, the means and standard deviations of the three competency indicators were analyzed and compared. The results are presented in Table 6. Altogether, the extent of the need for professional development in the learning environment and diversity of learners is very high. This infers that they have a high priority for intensive and extensive continuing professional development in the learning environment and diversity of learners.

Table 6. Professional Development Needs of Kindergarten Teachers in Learning Environment and Diversity of Learners 


\begin{tabular}{llll}
\hline Indicators & Mean & SD & $\begin{array}{c}\text { Qualitative } \\
\text { Description }\end{array}$ \\
\hline $\begin{array}{l}\text { 1. Managed learner behavior constructively by applying } \\
\text { positive and non-violent discipline to ensure learning- }\end{array}$ & & 0.44 & Very High \\
focused environments. & & \\
2. Managed classroom structure to engage learners, & 4.72 & 0.49 & Very High \\
individually or in groups, in meaningful exploration, \\
discovery, and hands-on activities within a range of physical \\
learning environments.
\end{tabular}

Looking closer, the result shows that the extent of their professional development needs in managing learner behavior constructively by applying positive and non-violent discipline to ensure learning-focused environments garnered the highest response with a very high extent of professional needs. Followed by managing classroom structure in engaging learners, individually or in groups, in meaningful exploration, discover, and hands-on activities within a range of physical learning environments, also with a very high extent of professional needs. The extent their professional development needs in using differentiated, developmentally appropriate learning experiences to address learners' gender, needs, strengths, interests, and experiences earned the lowest response but still a very high extent, which suggests a high priority for intensive and extensive continuing professional development. The frequency responses in managing classroom structure in engaging learners, individually or in groups, in meaningful exploration, discover, and hands-on activities within a range of physical learning environments, and using differentiated, developmentally appropriate learning experiences to address learners' gender, needs, strengths, interests, and experiences are similar. This infers that their extents of needs for professional development in these domains are in the same extent.

The result simply shows that these participants highly wanted their teaching practices, skills, and knowledge in the learning environment and diversity of learners to be developed. Possibly, there is a need to enhance their efficacy in classroom management practices, improve their ability in managing students' behavior and develop their skills in establishing systems of classroom management and in using differentiated and appropriate instructions that are suitable to every learner. Moreover, the result implies that the participants desire to have professional developments in the three indicators for them to provide their learners with learning environments that are safe, secure, fair, and supportive in promoting learner responsibility and achievement.

The results of the study point to the fact that kindergarten teachers need continuing professional development in managing learner behavior and classroom structures to promote collaboration, active learning in the classroom and to achieve equal learning opportunities for the learners. This assertion supports the statement of Possi and Milinga (2017), which stated that teachers should be trained in effective classroom arrangements for them to be aware of the practices to respond to learner diversity and to achieve equal learning opportunities for the learners. Besides, this assertion conforms to the findings of Jelas (2010), which claimed that it is essential to have professional development for teachers for them to be able to deal with the diverse needs of learners and have a learning-friendly classroom. Additionally, the finding of the study suggests that it is a requisite to improve the ability of kindergarten teachers in managing students' behavior in a non-violent discipline through continuous professional development. This affirmation supports the findings of Sciuchetti and Yssel (2019), who said that teachers persistently need additional professional development programs in managing students' behavior in enforcing positive discipline for effective teaching and learning. Moreover, the findings of the study also suggest that the participants desire to engage in professional development training to develop their skills in using differentiated and appropriate instructions that are suitable for every learner. This impression supports the claim of Kwaku, Mensah, and Jonathan (2016), who said that teachers must participate in professional development programs to improve teaching and learning by enhancing teachers' quality and effective teaching by incorporating different approaches appropriate to every learner.

\subsection{Professional Development Needs in Curriculum and Planning}

To delineate the extent of the need for professional development in curriculum and planning of kindergarten teachers, the means and standard deviations of the three competency indicators were analyzed and compared. The results are presented in Table 7. Generally, the extent of professional development needs of kindergarten teachers in curriculum and planning is high which signifies that these teachers prioritize professional development in this indicator. Further, the results reveal that among the three indicators, selecting, developing, organizing, and using appropriate teaching and learning resources, including ICT, in addressing learning goals earned a very high response, which suggests that the participants have a high priority for intensive and extensive continuing professional development. With a mean difference of 0.06 , it is followed by planning, managing, and 
implementing developmentally sequenced teaching contexts, which also suggests that the participants have a high priority for intensive and extensive continuing professional development. However, participating in collegial discussions that use teacher and learner feedback in enriching teaching practice garnered the lowest response but a high extent, which indicates that it is the participants' priority for professional development. On the contrary, the researcher observed that the answers of kindergarten teachers in this indicator are widely dispersed. This draws an implication that the professional development needs of these teachers in this indicator are not similar. Some of the participants may still highly prioritize continuing professional development in participating in collegial discussions using teacher and learner feedback in enriching teaching practice.

Moreover, the general result indicates that these teachers seek to advance their knowledge, to plan, and design well-structured and organized lessons. As discussed earlier, the participants possessed a moderate level of competence in the two indicators, in selecting, developing, organizing, and using appropriate teaching and learning resources, including ICT. They have the same extent of professional development needs in addressing learning goals, and in planning, managing, and implementing developmentally sequenced teaching and learning processes in meeting curriculum requirements and varied teaching contexts, possibly this is the reason why they prioritize continuing professional development in these indicators to improve the level of their competence.

Table 7. Professional Needs of Kindergarten Teachers in Curriculum and Planning

\begin{tabular}{|c|c|c|c|}
\hline Indicators & Mean & SD & $\begin{array}{l}\text { Qualitative } \\
\text { Description }\end{array}$ \\
\hline $\begin{array}{l}\text { 1. Selected, developed, organized, and used appropriate } \\
\text { teaching and learning resources, including ICT, to address } \\
\text { learning goals. }\end{array}$ & 4.74 & 0.52 & Very High \\
\hline $\begin{array}{l}\text { 2. Planned, managed, and implemented developmentally } \\
\text { sequenced teaching contexts. }\end{array}$ & 4.68 & 0.46 & Very High \\
\hline $\begin{array}{l}\text { 3. Participated in collegial discussions that use teacher and } \\
\text { learner feedback to enrich teaching practice. }\end{array}$ & 3.79 & .95 & High \\
\hline Overall & 4.40 & .36 & High \\
\hline
\end{tabular}

The results of this study are comparable with the notion of the Curriculum Development Council (2017) which stated that kindergarten teachers should be given relevant professional development support and resources for the planning and implementation of the curriculum to provide appropriate, high quality with enriched learning experiences to the learners, as they are the implementers of the curriculum. Likewise, Morrison (2019) states that teachers wanted to undergo several pieces of training and continuous professional development to advance their understanding and abilities in using curriculum materials to ensure high-quality delivery of instruction. Additionally, sharing and working together can contribute to providing quality teaching and learning process as teachers may learn from each other's experiences and knowledge. This impression supports the notion of Ajani, Govender, Maluleke, (2018), which states that teachers should be mentored by specialized, experienced, and expert teachers and should engage in social interactions, networking, and collaborations to improve classroom instructions. Also, the general results of the study point to the fact that the participants wanted to acquire professional development programs in curriculum and planning to increase their ability in translating curriculum content into learning activities suited to learners, as well as in communicating learning goals to solicit active participation of the learner to promote understanding and achievement. This realization conforms to the statement of Nghihalwa (2018), which states that teachers should be trained and guided to gear them in implementing curriculum to address learning goals.

\subsection{Professional Development Needs in Assessment and Reporting}

Table 8 presents the results that describe the extent of the professional development needs of kindergarten teachers. The means and standard deviations of professional development need indicators were analyzed and compared to describe the extent of the professional development needs of the participants in assessment and reporting. Their overall extent of professional development needs in assessment and reporting is high, which suggests that these teachers prioritize professional development. Among the three professional development need indicators, designing, selecting, organizing, and using diagnostic, formative, and summative assessment strategies consistent with curriculum requirements earned a high response described to a very high extent. It was succeeded by monitoring and evaluating learner progress and achievement using learner attainment data, still earned a high response delineate to as a very high extent. These mean they have a high priority for intensive and extensive continuing professional development in these indicators. Further, the researcher observes that the extent of professional development need of the participants in communicating promptly and learners' needs, progress and achievement to key stakeholders, including parents/guardians got the lowest ratings with a low extent which indicates that this competency may be included for professional enhancement, but it is not a priority. However, their answers in this professional need indicator are widely spread compared to the other two professional need indicators. This shows that their professional development needs in this indicator are not similar. The results imply 
that the participants are knowledgeable and equipped with adequate skills and strategies in communicating promptly and learners' needs, progress, and achievement to key stakeholders and parents/guardians. It is supported by the results of Table 6 that shows that the participants possessed most of the competencies of efficient teachers in this indicator. But, the frequency of their responses indicates that some participants still in need of continuing professional development in this indicator. Possibly those teachers are those new in the service. This assertion supports the ideas of Mizell (2010), who said that novice teachers need extra support like professional development training, induction programs, and mentoring to learn effective practices for them to apply to the new, unfamiliar challenges or issues they may encounter and would become effective educators. Further, the results of the study support the findings of Pang and Leung (2011). They stated that early childhood teachers should be given numerous professional development programs, as some teachers were incapable of giving quality feedback to the parents that could help in improving students' learning.

Table 8.Professional Needs of Kindergarten Teachers in Assessment and Reporting

\begin{tabular}{llll}
\hline Indicators & Mean & SD & $\begin{array}{l}\text { Qualitative } \\
\text { Description }\end{array}$ \\
\hline $\begin{array}{l}\text { 1. Designed, selected, organized, and used diagnostic, } \\
\text { formative, and summative assessment strategies consistent } \\
\text { with curriculum requirements. }\end{array}$ & & 0.63 & Very High \\
$\begin{array}{l}\text { 2. Monitored and evaluated learner progress and achievement } \\
\text { using learner attainment data. }\end{array}$ & & & \\
$\begin{array}{l}\text { 3. Communicated promptly and learners' needs, progress, } \\
\text { and achievement to key stakeholders, including } \\
\text { parents/guardians. }\end{array}$ & & 0.69 & Very High \\
\hline Overall & 3.87 & & Low \\
\hline
\end{tabular}

Further, this study points to the fact that the participants long for several professional development training in designing, selecting, organizing, and using assessment strategies consistent with the curriculum requirements for them to be able to enhance the teaching and learning process by possessing adequate assessment techniques and practices in grading. This assumption is parallel to the notion of the Organization for Economic Co-Operation and Development (2009), which states that it is necessary to strengthen teachers' skills and capacity in developing and conducting appropriate assessment tools and techniques through professional development programs. Moreover, greater emphasis on involving kindergarten teachers in professional development programs is essential to improve their assessment literacy and to meet their needs in improving their competence in assessment consistent with the curriculum requirements. This supports the findings of Zamri and Hamzah (2019), that stated that teachers' competency in assessment is very important in the implementation of effective classroom assessment coherent to assessment objectives. It also supports the findings of Gonzales and Callueng (2008). They found that in-service professional development programs should be designed coherently to their specific needs to provide teachers ample knowledge on assessment tools and techniques, as they need to use a variety of assessment tools to provide more assessment activities in ensuring objectivity in the determination of the performance of students.

Furthermore, the general result implies that the participants want to improve their knowledge and skills in assessment and reporting. Maybe because they wanted to be equipped with the latest trend in assessing their learners and what are the best practices in giving feedback to the stakeholders or parents and guardians. This assumption supports the findings of Dayal and Lingam (2015), and Al-malki and Weir (2014). They claimed that despite having many years of teaching, the majority of the teachers have a narrow understanding of assessment, so teachers should prioritize teacher development programs to develop their assessment competencies. Additionally, the result of the study backs up the findings of Hailaya (2014), who found that teachers with low assessment literacy negatively influenced their teaching practices. To increase teachers' competence in classroom assessment, teachers need to acquire assessment expertise. Teachers should be given more relevant in-service training.

\section{CONCLUSION}

Kindergarten teachers are competent and can obtain most of the competencies of efficient teachers in four domains. Though they perceived themselves to have acquired most of the competencies of efficient teachers, they recognized the importance of continuing and lifelong learning. In particular, they want to acquire more information on early childhood teaching, especially on the content knowledge and pedagogy as well as on the learning environment and diversity of learners. These areas are their high priority for training and would be the prime considerations in the crafting of a professional development plan in the locale. 


\section{REFERENCES}

1. Ajani, O. A., Govender, S. \& Maluleke, N. (2018). Teachers' In-Service Professional Development: Gateway to Improved Classroom Practices in Nigerian Schools. Journal of Gender, Information, and Development in Africa, 7(3), 21-40. Retrieved from https://bit.ly/36AOUcB

2. Al-malki, M. A. \& Weir, K. (2014). A Comparative Analysis between the Assessment Criteria Used to Assess Graduating Teachers at Rustaq College (Oman) and Griffith University (Australia) During the Teaching Practicum. Australian Journal of Teacher Education, 39 (12), 27-42. Retrieved from https://bit.ly/2M6kQwi

3. Allan, M. R. (2008). Qualitative Study of Kindergarten School Readiness and Personal and Social Development. Richmond, Virginia: Virginia Polytechnic Institute and State University.

4. Amirul, N. J., Ahmad, C. N. C., Yahya, A., Abdullah, M. F. N. L., Adnan, M. \& Noh, N. M. (2013). The physical classroom learning environment (Sultan Idris Education University). Retrieved from https://bit.ly/3eukFXL

5. Avidov-ungar, O. (2018). A model of professional development: teachers' perceptions of their professional development. Teachers and Teaching, 22:6 (March 2016), 653-669. Retrieved from https://doi.org/10.1080/13540602.2016.1158955

6. Board on Children, Youth, and F. (2015). Child Development and Early Learning: A Foundation for Professional Knowledge and Competencies. Retrieved from httpswww.nap. eduresource19401 ProfKnowCompFINAL.pdf

7. Chaudhary, G. K. (2015). Factors affecting curriculum implementation for students. International Journal of Applied Research, 1(12), 984-986. Retrieved from https://bit.ly/3hkC32m

8. Curriculum Development Council. (2017). Kindergarten Education Curriculum Guide Joyful Learning through PLay Balanced Development All the Way. Retrieved from https://www.edb.gov.hkattachmentencurriculum-developmentmajor-level-ofedupreprimaryENG_KGECG_2017.pdf

9. Dayal, H. C.\& Lingam, G. I. (2015). Fijian Teachers' Conceptions of Assessment Fijian Teachers' Conceptions of Assessment. Australian Journal of Teacher Education, 40(8), 42-58.

10. Department of Education-Teacher Education Council. (2017). Philippine Professional Standards for Teachers. Retrieved from https://en.wikipedia.org/wiki/President_Quirino,_Sultan_Kudarat

11. Department of Education (2016). DO 35 s, 2016 - The Learning Action Cell as a K to 12 Basic Education Program School-Based Continuing Professional Development of Teaching and Learning.

12. Elliot, P. (2019). Practice What We Teach: Using the TPACK Framework to Connect Professional Development and Academic Programs and Processes. College and University, 93(4), 16-24. Retrieved from https://www.aacrao.orgdocsdefault-sourcec-u-.pdfscuj9304-web.pdfsfvrsn=94408324_2

13. Evens, M., Elen, J.\& Depaepe, F. (2015). Developing Pedagogical Content Knowledge : Lessons Learned from Intervention Studies. Education Research International, 2015(1), 23. Retrieved from http://downloads.hindawi.comjournalsedri2015790417.pdf

14. Ghavifekr, S.\& Rosdy, W. A. W. (2015). Teaching and Learning with Technology : Effectiveness of ICT Integration in Schools Teaching and Learning with Technology : Effectiveness of ICT Integration in Schools. International Journal of Research in Education and Science, 1(2), 175-191. Retrieved from httpsfiles.eric.ed.govfulltextEJ1105224.pdf

15. Gonzales, R. D.\& Callueng, C. M. (2008). Classroom Assessment Practices of Filipino Teachers: Measurement and Impact of Professional Development. Essentials on Counseling and Education, 220-243.

16. Guskey, T. R. (2013). Does It Make a Difference ? Evaluating Professional Development. ASCD, 59(6), 45 51. Retrieved from https://pdo.ascd.org LMSCoursesPD 13OC010MmediaLeading_ Prof_Learning M6_Reading1.pdf

17. Hailaya, W. M. (2014). Teacher Assessment Literacy and Student Outcomes in the Province of Tawi-Tawi, $\begin{array}{lllll}\text { Philippines (University of Adelaide). } & \text { Retrieved }\end{array}$ https://digital.library.adelaide.edu.audspacebitstream244099098202whole.pdf

18. Ho, C. L. (n.d.). Continuing Professional Development. Retrieved from https://www.childcarelink.gov.sg/ccls/uploads/CPD_Guide_5_FA.pdf

19. Jelas, Z. M. (2010). Learner Diversity and Inclusive Education: A New Paradigm for Teacher Education in Malaysia. Procedia Social and Behavioral Sciences, 7(2), 201-204. https://doi.org/10.1016/j.sbspro.2010.10.028

20. Kwaku, D., Mensah, D. \& Jonathan, A. W. (2016). Teacher Professional Development: Keys to Basis School Teachers' Curriculum Practice Success in Ghana. British Journal of Education, 4(4), 29-37. Retrieved from http://www.eajournals.orgwp-contentuploadsTeacher-Professional-Development1.pdf

21. Lee, Y. (2011). Enhancing pedagogical content knowledge in a collaborative school-based professional development program for inquiry-based science teaching. Asia-Pacific Forum on Science Learning and Teaching, 12(2), 1-29. Retrieved from https://www.eduhk.hkapfsltdownloadv12_issue2_filesleeyc.pdf 
22. Lucenario, J. L. S., Yangco, R. T., Punzalan, A. E. \& Espinosa, A. A. (2016). Pedagogical Content Knowledge-Guided Lesson Study: Effects on Teacher Competence and Students 'Achievement in Chemistry. Hindawi Publishing Corporation Education Research International, 2016. Retrieved from http://downloads.hindawi.comjournalsedri20166068930.pdf

23. Malik, R. H.\& Rizvi, A.A. (2018). Effect of Classroom Learning Environment on Students 'Academic Achievement in Mathematics at Secondary Level. Bulletin of Education and Research, 40(2), 207-218. Retrieved from https://files.eric.ed.govfulltextEJ1209817.pdf

24. Margarita, M.\& Ancheita, G. (2005). The Impact of the Learning Environment on a Child's Behavior. Retrieved from https://ufdcimages.uflib.ufl.eduUFE001138700001garcia_m.pdf

25. Mertler, C. A. (2003). Preservice Versus Inservice Teachers' Assessment Literacy: Does Classroom Experience Make a Difference? Mid- Western Educational Research Association, 10(00). Retrieved from https://www.researchgate.netpublication329815072_Teachers_Competence_in_the_Educational_Assessme nt_of_Students_The_Case_of_Secondary_School_Teachers_in_the

26. Mizell, H. (2010). Why Professional Development Matters (V. von Frank, Ed.). Retrieved from www.learningforward.org/advancing/whypdmatters.cfm

27. Morrison, K. (2019). Perceptions of the Impact of Quality Professional Development on the Sustainability of a one-to-one Computing Initiative at the High School Level. i-manager's Journal on School Educational Technology, 14(4), 17-37. Retrieved from https://doi.org/https://doi.org/10.26634/jsch.14.4.16039

28. Nghihalwa, I. N. (2018). Teachers' Involvement in the Planning and Development of National Curriculum for Basic Education in Namibia (University of Eastern Finland). Retrieved from http://epublications.uef.fipuburn_nbn_fi_uef-20181250urn_nbn_fi_uef-20181250.pdf

29. Nicholas, M. (2015). Student Knowledge : Curriculum, Asssessment, and Reporting. Journal of Educational Enquiry, 14(December), 1-16. Retrieved from https://www.researchgate.netpublication285458427_Student_Knowledge_Curriculum_Assessment_and_Re porting

30. Opfer, V. D.\& Pedder, D. (2011). The lost promise of teacher professional development in England. European Journal of Teacher Education, 34(1), 3-24. Retrieved from https://doi.org/10.1080/02619768.2010.534131

31. Organization for Economic Co-Operation and Development. (2009). Creating Effective Teaching and Learning Environments: First Results from TALIS. Retrieved from http://www.oecd.org/education/school/50456114.pdf

32. Özerem, A.\& Akkoyunlu, B. (2015). Learning Environments Designed According to Learning Styles and Its Effects on Mathematics Achievement. Eurasian Journal of Educational Research, (61), 61-80. https://doi.org/http://dx.doi.org/10.14689/ejer.2015.61.4

33. Pang, N. S.\& Leung, Z. L. (2011). for Learning in Early Childhood Education in Hong Kong. Educational $\begin{array}{llll}\text { Research } & \text { 26(2), } & 199-222 . & \text { Retrieved }\end{array}$ httpciteseerx.ist.psu.eduviewdocdownloaddoi=10.1.1.1009.4892\&rep=rep1\&type=pdf

34. Patankar, P. S. \& Jadhav, M. S. (2013). Role of Teachers' in Curriculum Development for Teacher Role of Teachers' in Curriculum Development for Teacher Education (Shivaji University, Kolhapur). Retrieved from https://www.researchgate.net/publication/258023165\%0AROLE

35. Philippine National Research Center for Teacher Quality. (2017). Philippine Professional Standards for Teachers.

36. Possi, M. K. \& Milinga, J. R. (2017). Learner Diversity in Inclusive Classrooms : The Interplay of Language of Instruction, Gender, and Disability. Malaysian Online Journal of Educational Sciences, 5(3), $28-45$. Retrieved from https://files.eric.ed.govfulltextEJ1150435.pdf

37. Rahman, F., Jumani, N. B., Akhter, Y., Chisthi, S. ul H.\& Ajmal, M. (2011). Relationship between Training of Teachers and Effectiveness Teaching. International Journal of Business and Social Science, 2(4), 150-160. Retrieved from http://ijbssnet.comjournalsVol._2_No._4;_March_201118.pdf

38. Sağır, M. (2014). Teachers ' Professional Development Needs and the Systems That Meet Them. Creative Education, 5, 1497-1511. Retrieved from https://doi.org/http://dx.doi.org/10.4236/ce.2014.516167

39. Sawari, S. S. M. (2014). Teacher Competency Assessment in the Classroom: Current Issues Teacher Competency Assessment in the Classroom: Current Issues. International Journal of Informative and Futuristics Research, 1(3), 90-96. Retrieved from https://www.researchgate.netpublication 268209278_Teacher_Competency_Assessment_in_the_Classroom_Current_Issuesrelated

40. Sciuchetti, M. B. \& Yssel, N. (2019). The Development of Preservice Teachers' Self- Efficacy for Classroom and Behavior Management Across Multiple Field Experiences. Australian Journal of Teacher Education, 44(6). Retrieved from https;//ro.ecu.edu.au/ajte/vol44/iss6/2

41. Selvi, K. (2016). Teachers ' Competencies. International Journal of Philosophy of Culture and Axiology, (January), 168-175. Retrieved from https://doi.org/10.5840/cultura20107133 
42. Tagele, A.\& Bedilu, L. (2018). Teachers' Competence in the Educational Assessment of Students : The Case of Secondary School Teachers in the Amhara National Regional State Students: The Case of Secondary School Teachers in the Amhara. The Ethiopian Journal of Education, 15 (December 2015), 163.

43. Tanang, H.\& Abu, B. (2014). Teacher Professionalism and Professional Development Practices in South Sulawesi, Indonesia. Journal of Curriculum and Teaching, 3(2), 25-42. Retrieved from https://doi.org/10.5430/jct.v3n2p25

44. Zaidi, S., Khan, N. R.\& Khan, N. (2018). Organizational_Factors_Teachers_Professi httpswww.academia.edupeoplesearchutf $8=\& q=$ professional+development+for+curriculum+teaching+areas. pdf. International Journal of Experiential Learning and Case Studies, 3(1), 84-96. Retrieved from https://www.academia.edupeoplesearchutf $8=\& q=$ professional+development+for+curriculum+teaching+are as

45. Zamri, M. N. B.\& Hamzah, M. I. B. (2019). Teachers' Competency in Implementation of Classroom Assessment in Learning. Creative Education, 3(1), 2939-2946. Retrieved from https://doi.org/10.4236/ce.2019.1012218

46. Zhang, Y. \& Chicago, I. (2015). Pedagogical Content Knowledge in Early Mathematics: What Teachers Know and how it Associates with Teaching and Learning. East Eisenhower Parkway: ProQuest LLC. 